\title{
Perception Survey, Mental Health and Social Media Exposure in Adolescents during The COVID-19 Pandemic
}

\author{
Efa Nugroho $^{1}$, Alfiana Ainun $\mathrm{Nisa}^{2}$, Arumia Prasya Atikassyifa ${ }^{3}$ \\ \{efa.nugroho@mail.unnes.ac.id ${ }^{1}$, alfiana_ainun@mail.unnes.ac.id ${ }^{2}$, \\ prasya.arumiia@students.unnes.ac.id $\left.{ }^{3}\right\}$ \\ Universitas Negeri Semarang, Semarang, Indonesia ${ }^{1,2,3}$
}

\begin{abstract}
In the event of an outbreak, the emergency will depress the community, which can affect the health conditions of the community. The COVID19 pandemic has a profound effect on all aspects of society, including mental health and physical health. The risk of decreased physical and mental health can attack vulnerable groups such as the elderly, adolescents, and children. The author explores perceptions, and social media exposure during the COVID-19 pandemic. Research data will be used to develop strategies to reduce the psychological impact that may arise during a pandemic. The purpose of this study was to survey adolescents to better understand the impact of social exposure on perception during the COVID-19 pandemic. The survey was conducted on adolescents aged 10-24 years. A total of 1357 adolescents participated in this survey The survey method was carried out online. Teenagers fill out survey forms online with certain applications. -
\end{abstract}

Keywords: Perception, Social Media Exposure, Adolescents, Covid-19

\section{Introduction}

COVID-19 caused panic around the world since the end of 2019. Initially, the disease was named temporarily as the 2019 novel coronavirus (2019-nCoV), then WHO announced a new name on February 11, 2020 namely Coronavirus Disease (COVID-19) caused by the virus Severe Acute Respiratory Syndrome Coronavirus-2 (SARS-CoV-2) [1]. In March 2020 WHO announced COVID-19 as a pandemic [2]. Hundreds of thousands of people are infected, even thousands more have died. This virus was first discovered in Wuhan, China and has infected as many as tens of thousands of people. The source of the host is thought to come from animals, especially bats. This virus can be transmitted from human to human. Symptoms that are usually seen include fever, coughing and difficulty breathing.

The Indonesian government issued a state of disaster emergency on 29 February 2020 related to the COVID-19 pandemic [3]. One of the steps taken by the government to prevent the transmission of this virus is by staying at home and implementing social distancing. This 
step was taken to break the chain of transmission of COVID-19 by keeping a safe distance between people at least 1 meter, and not making direct contact with others, avoiding crowds and mass gatherings. [4]

The distribution of COVID-19 cases on 30 June 2020 in Indonesia was 56,385 which was confirmed positive, 24,806 were recovered and 2,876 died [5]. Cases in Central Java were found as many as 4,025 positive cases of the Corona virus, 1,820 of whom were treated (45.22 percent), 1,878 recovered (46.66 percent), and 327 died (8.12 percent). [6] Central Java is recorded as one of the five provinces with the highest number of COVID-19 cases in Indonesia, besides East Java, Sulawesi, DKI Jakarta and South Kalimantan. [5]. At present, Central Java is entering COVID-19 emergency status.

Humans as social creatures need communication to exchange information. The development offlows globalizationhas an impact on the development of Information and Communication Technology (ICT). One form of progress from ICT is social media [7]. Social media has become part of the modern lifestyle for various activities. Social media has a very important role in radically changing the lifestyle of people communicating and interacting [8]. Social media in the form of social networks and blogs make it easier for everyone to connect. Social media is a digital platform that provides information sharing / exchange facilities, usercontent -generated(can be ideas, images, videos, and audio-videos), and collaboration between people through a network [9]. In addition, social media has the potential to revolutionize organizational behavior.[10]. During the time of silence at home, many people who use devices to connect with the outside world. Some applications that are often used are social media. This phenomenon triggers researchers to conduct a survey of the impact of social media exposure on perception and mental health in adolescents.

\section{Methods}

Location of the research conducted was in Central Java. The population in this study were adolescents aged 10-24 years who were male and female, the method used in this study was a survey. Where this survey was conducted online in adolescents in the age range of 10-24 years. A total of 1357 adolescents participated in this survey The survey method was carried out online. Teenagers fill out survey forms online with certain applications. To obtain the validity and reliability of the data the credibility, dependability, transferability and confirmability assessments are carried out, so that the findings can be trusted and have the accuracy of the data produced. This will be used to measure the level of perception and social media exposure of adolescents during the COVID-19 pandemic. The data used in this study are qualitative data. The type of research conducted is descriptive analysis, which provides education and understanding to the reader, and the type of data used in this study is secondary data.

\section{Results and discussion}

\subsection{Adolescent Characteristics}

According to the Population and Family Planning Agency (BKKBN) the age range of teenagers is 10-24 years and not yet married. The total number of adolescents who filled the 
survey was 1357 adolescents. The number of early adolescents aged 10-14 years is 83 children. The number of middle adolescents aged 15-18 years is 494 children. The number of late teens aged 19-24 years was 778 children. the sexes of adolescents are grouped in 407 male and 950 girls.

Table 1. Adolescent characteristics

\begin{tabular}{lr}
\hline Age & \\
\hline $10-14$ years & 85 \\
$15-18$ years & 494 \\
19-24 years & 778 \\
\hline Gender & 407 \\
\hline Male & 950 \\
\hline Girls & 23 \\
\hline Education & 68 \\
Not completed & 254 \\
Graduated from Elementary school & 970 \\
Graduated from Middleschool & 42 \\
Graduated from Hightschool & 14 \\
Graduated & 10 \\
\hline Job & 1318 \\
Not working yet & 15 \\
Teacher & \\
Student & 948 \\
Private & 409 \\
\hline Homebase & \\
\hline Countryside & \\
Urban & \\
\hline
\end{tabular}

Characteristic of adolescents according to age can influence the formation of adolescent perceptions. This statement is consistent with the theory of Robbins and Judge that the variables of gender, age, level of education, and social status affect perception. [11] Turban, King, Lee, Liang, and Turban define a dependent digital generation as a representation of the young generation who are growing up in the world of broadband connections, continually connecting with information technology, and being uncomfortable when they do not have access to the internet. [12]

A total of 970 teenagers graduated high school/equivalent. There are 1258 teenagers who are students. The main activity of teenagers is going to school or college. During the pandemic, schools were closed, so teenagers had to go to school and study from home. In rural areas than urban youth. This condition is caused because many adolescents who go to school or study in urban areas must return to their homes during the pandemic. The number of adolescents who are aged 10-24 years in rural areas is 948 children, while the number of adolescents in urban areas is 409 children. The number of teenagers in rural areas is almost double that of urban teenagers. 
Health conditions of adolescents must remain awake and must remain in prime condition during the pandemic mas. Mental health will make life satisfaction closely related to happiness where happy people will have a high immune system so they can ward off the outbreak of the virus [13]. A total of 661 adolescents are in good health, and only 51 adolescents feel in poor health. When associated with the Covid-19 pandemic, it is better for humans to think and interpret the positive side of the presence of the plague. then humans will be in a state of calm and alert adalam facing this plague. Besides that humans will also be better prepared and stronger in the face of other traumatic events in the future [14]

Next thing become an important concept in maintaining mental health is communication / interaction between all members family. Using communication and interaction as amechanism defenseto go through difficult times during the COVID-19 pandemic. There are 793 teenagers who agree that before Covid 19 communication / interaction between all family members was in good condition. In fact, there are as many as 736 adolescents stating that communication/interaction between all family members remained incondition good at the time of the Covid pandemic 19.

\subsection{Perception}

There are 442 teenagers who agree that their health will be damaged if exposed to the corona virus. SARS-CoV-2 transmission from symptomatic patients occurs through droplets that come out when coughing or sneezing [15]. Clinical manifestations of COVID-19 patients have a broad spectrum, ranging from asymptomatic, mild symptoms, pneumonia, severe pneumonia, ARDS, sepsis, to septic shock.. How large the proportion of asymptomatic infections is unknown [16]. The course of the disease begins with an incubation period of about 314 days (median 5 days). Some cases show the course of the disease in patients with severe COVID- 19, even more severe than the flu. There are 497 teenagers who agree that COVID19 is heavier than the flu.

Some of the other risk factors set forth by the Centers for Disease Control and Prevention (CDC ) iscontact close, including living with a COVID-19 patient and a history of travel to the affected area. Being in one environment but not in close contact (within a 2 meter radius) is considered a low risk. [17] Medical personnel are one of the populations at high risk of contracting. Hospitals are prioritized for the management of COVID-19 and illnesses with emergencies that must be dealt with immediately. There are 433 adolescents who do not agree if they have another disease, they not willgo to the hospital because of the risk of getting a new corona virus in the hospital. This illustrates that teenagers perceive that it is still safe if they go to the hospital, regardless of the risk of contracting other diseases.

Table 2. Perception

\begin{tabular}{lr}
\hline My health will be damaged if exposed to coronavirus & \\
\hline Agree & 442 \\
Disagree & 142 \\
Don't know & 33 \\
Neutral & 437 \\
Very Agree & 186 \\
Very Disagree & 117 \\
\hline Coronavirus is worse than the flu & 497 \\
\hline Agree & 66 \\
Disagree & 16 \\
Don't know & \\
\hline
\end{tabular}




\begin{tabular}{|c|c|}
\hline Neutral & 343 \\
\hline Very Agree & 328 \\
\hline Very Disagree & 107 \\
\hline \multicolumn{2}{|c|}{ Won't go to the hospital because of the risk of getting coronavirus in the hospital } \\
\hline Agree & 229 \\
\hline Disagree & 433 \\
\hline Don't know & 44 \\
\hline Neutral & 406 \\
\hline Very Agree & 78 \\
\hline Very Disagree & 167 \\
\hline \multicolumn{2}{|c|}{ Coronavirus caused serious damage to the surrounding community } \\
\hline Agree & 473 \\
\hline Disagree & 100 \\
\hline Don't know & 36 \\
\hline Neutral & 408 \\
\hline Very Agree & 224 \\
\hline Very Disagree & 116 \\
\hline \multicolumn{2}{|c|}{ The risk of corona virus will spread widely in Central Java } \\
\hline Agree & 205 \\
\hline Disagree & 261 \\
\hline Don't know & 124 \\
\hline Neutral & 476 \\
\hline Very Agree & 73 \\
\hline Very Disagree & 218 \\
\hline \multicolumn{2}{|c|}{ I can protect myself from the corona virus } \\
\hline Agree & 480 \\
\hline Disagree & 62 \\
\hline Don't know & 39 \\
\hline Neutral & 431 \\
\hline Very Agree & 245 \\
\hline Very Disagree & 100 \\
\hline \multicolumn{2}{|c|}{ I can protect myself from the corona virus better than anyone else } \\
\hline Agree & 353 \\
\hline Disagree & 105 \\
\hline Don't know & 69 \\
\hline Neutral & 598 \\
\hline Very Agree & 156 \\
\hline Very Disagree & 76 \\
\hline
\end{tabular}

A total of 473 teenagers agree that COVID -19 will causing serious damage to the community around them, both in terms of social and economic.Total 476 adolescents declared neutral that COVID 19 would be widespread in Central Java. When compared with the results of the research a little different, especially related to the COVID incident in Central Java.cases Positive confirmed patientare increasing in Central Java.

A total of 480 teens perceive that they can protect themselves from COVID-19. This is because many teenagers who know several ways of prevention that they can do. Even as many as 446 adolescents believe that they can protect themselves from the corona virus better than anyone else. WHO recommendations in dealing with the COVID-19 outbreak are basic protection, which consists of washing hands regularly with alcohol or soap and water, keeping a distance from someone who has symptoms of coughing or sneezing, conducting ethic cough- 
ing or sneezing, and seeking treatment when having complaints that are according to the suspect category.

Recommended distance to maintain is one meter [18]. Soap can lift and break down compounds hydrophobicsuch as fat or oil. [19] In addition to using water and soap, ethanol 62$71 \%$ can reduce viral infectivity. [20] Avoid touching the face especially the face, nose or mouth with the surface of the hand. When the hands are contaminated with a virus, touching the face can be an entry portal. Finally, be sure to use one-time tissue when sneezing or coughing to avoid spreading droplets [21]

\subsection{Mental Health}

Table 3. Mental Health

\begin{tabular}{lr}
\hline I feel cheerful and uplifting & \\
\hline $1-3$ days & 69 \\
$4-6$ days & 76 \\
$7-9$ days & 239 \\
10-13 days & 182 \\
Everyday & 764 \\
Never & 27 \\
\hline I feel calm and relaxed & 51 \\
\hline $1-3$ days & 72 \\
$4-6$ days & 208 \\
$7-9$ days & 153 \\
$10-13$ days & 834 \\
Everyday & 39 \\
Never & \\
\hline I feel active and excited & 75 \\
\hline 1-3 days & 83 \\
4-6 days & 248 \\
7-9 days & 213 \\
Everyday & 701 \\
Never & 37 \\
\hline I wake up feeling refreshed & \\
\hline $1-3$ days & 64 \\
4-6 days & 63 \\
10-13 days & 219 \\
Everyday & 167 \\
Never & 791 \\
\hline 1-3 days & 53 \\
$4-6$ days & 172 \\
\hline 10-13 days & \\
\hline
\end{tabular}




\begin{tabular}{|c|c|}
\hline Everyday & 734 \\
\hline Never & 63 \\
\hline \multicolumn{2}{|c|}{ Feeling nervous, anxiety, or anxious } \\
\hline 1-3 days & 605 \\
\hline 4-6 days & 203 \\
\hline 7-9 days & 155 \\
\hline 10-13 days & 105 \\
\hline Never & 289 \\
\hline \multicolumn{2}{|c|}{ Can't stop or control worries } \\
\hline 1-3 days & 584 \\
\hline 4-6 days & 190 \\
\hline 7-9 days & 133 \\
\hline 10-13 days & 64 \\
\hline Never & 386 \\
\hline \multicolumn{2}{|c|}{ Feeling difficulty relaxing } \\
\hline 1-3 days & 519 \\
\hline 4-6 days & 193 \\
\hline 7-9 days & 164 \\
\hline 10-13 days & 86 \\
\hline Never & 395 \\
\hline \multicolumn{2}{|c|}{ Get very nervous } \\
\hline 1-3 days & 555 \\
\hline 4-6 days & 137 \\
\hline 7-9 days & 99 \\
\hline 10-13 days & 37 \\
\hline Never & 529 \\
\hline \multicolumn{2}{|c|}{ Gets irritated easily } \\
\hline 1-3 days & 503 \\
\hline 4-6 days & 226 \\
\hline 7-9 days & 222 \\
\hline 10-13 days & 122 \\
\hline Never & 284 \\
\hline \multicolumn{2}{|c|}{ Feeling scared as if something bad is about to happen } \\
\hline 1-3 days & 575 \\
\hline 4-6 days & 186 \\
\hline 7-9 days & 167 \\
\hline 10-13 days & 98 \\
\hline Never & 331 \\
\hline
\end{tabular}

For the past 2 weeks, some teens feel that they are in a good and pleasant mental state every day. 764 adolescents felt cheerfull and uplifting, 834 adolescents felt calm and relaxed, 701 fell active and excited, 791 awoke feeling refreshed, and 734 adolescents felt their daily life was full of interesting things. 
There are several psychiatric problems that adolescents experience during the pandemic. but the average teenager can overcome problems that arise due to psychiatric disorders for 1-3 days. There are 605 teenagers feel nervous, anxiety, or anxious for only 1-3 days. 584 adolescents can stop or control worries, 519 adolescents who have difficulty relaxing only for 1-3 days. 555 teens get very nervous, 503 teens get irritated easily, 575 Feeling scared as if something bad is about to happen. this data shows that adolescent mental health is in a stable condition for the past 2 weeks. teens don't need a long time to experience mental health disorders, and they tend to be more able to solve them.

\subsection{Social Media Exposure}

A total of 1191 teenagers access whatsapp, 1072 teenagers access Instagram and several other social media. Survey results indicate that teenagers very often accessing social media, there are as many as 446 adolescents who say that. This provides information that the average social media usage activity is almost equivalent to 8 hours of employee work. If access to social media is used for positive things, then productivity can be increased in all respects. The positive impact of using social media is teenagers get entertainment, get information, and can strengthen social relationships with others. In addition to the positive effects felt by adolescents, negative impacts also arise, for example the exposure of adolescents about HOAX news about COVID19 which can cause anxiety and misperceptions occur in adolescents.

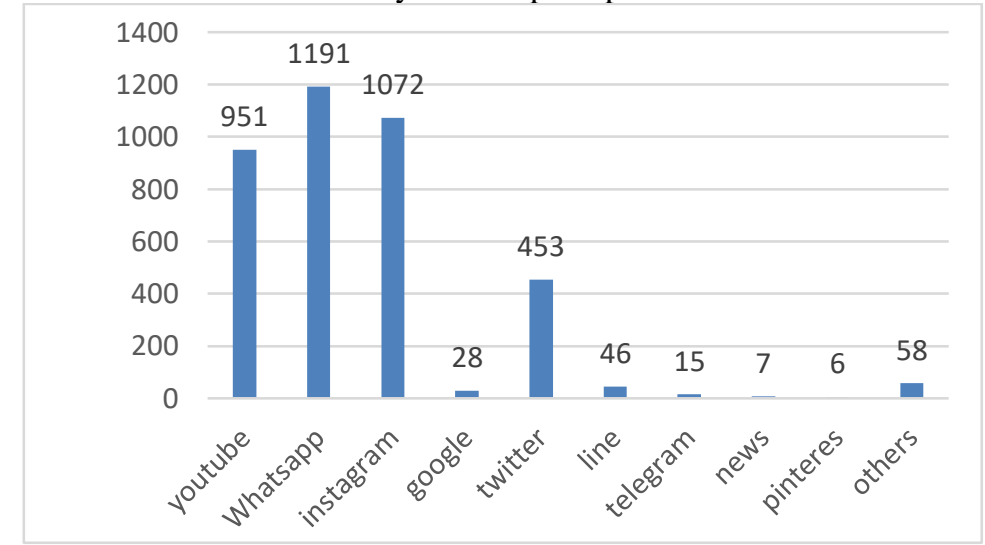

Fig. 1 Social media

Table 4. Social media exposure

\begin{tabular}{lr}
\hline In one day, how often do you Access social media (Before the Pandemic COVID-19) \\
\hline Very often & 191 \\
Often & 517 \\
Sometimes & 404 \\
Once in a while & 206 \\
Never & 39 \\
\hline In one day, how often do you access social media (After the Pandemic COVID-19) \\
\hline Very often & 446 \\
Often & 410 \\
Sometimes & 276 \\
Once in a while & 191 \\
Never & 34 \\
"Table 4 (Continued)" & \\
\hline
\end{tabular}




\begin{tabular}{lr}
\hline In one day, how often do you access information about COVID-19 on social media \\
\hline Very often & 128 \\
Often & 388 \\
Sometimes & 491 \\
Once in a while & 284 \\
Never & 66 \\
\hline In one day, how often did you share information about COVID-19 \\
\hline Very often & 40 \\
Often & 174 \\
Sometimes & 483 \\
Once in a while & 425 \\
Never & 235 \\
\hline
\end{tabular}

Social media exposure to adolescents can be seen in the table. Before the COVID-19 pandemic in one day 517 adolescents often accessed social media, even after the COVID-19 pandemic there were 446 adolescents whose frequency of accessing social media more often in one day.

Based on the table there are 128 teenagers who very often access information about COVID 19 on social media. This is interesting because only a few teenagers use social media to find information about COVID 19. There are 66 teenagers who have never even used social media to access information about COVID19. It is undeniable that teenagers need entertainment in the form of information about entertainment, culinary, and other entertainment topics besides COVID19 topics. There are as many as 40 teenagers who very often share information about COVID 19 after getting information from social media. But there are 235 teenagers who never share information about COVID after getting information from social media. Further research needs to be done whether the information conveyed on social media can be justified. Because a lot of HOAX news circulating on social media about the COVID19 topic.

\section{Conclusion}

During the pandemic many teenagers access social media. Some even have frequent frequencies in accessing social media. There are 128 teenagers who access information about COVID 19 and 40 of them spread information about COVID 19 that they get. Exposure to social media influences adolescents' perceptions of COVID 19. Adolescents assume that they can protect themselves from COVID 19 by taking basic preventative measures, where these steps are widely promoted through social media. The benefits of using social media in shaping adolescent perceptions include promoting preventive measures, selling items that can be used as personal protective equipment, studying adolescent perceptions by listening to their conversations onsocial media and providing support services to adolescents to answer questions about COVID19. The implication of this research for adolescents is to wisely use social media. Be aware of the positive and impacts negative of social media and wise in responding to misleading information about COVID 19.

\section{Acknowledgement}

This study received grants from DIPA PNBP Faculty of Sport Science Universitas Negeri Semarang year 2020/2021. 


\section{References}

[1] World Health Organization. Naming the coronavirus disease (COVID-19) and the virus that causes it [Internet]. Geneva: World Health Organization; 2020 [cited 2020 March 29].

[2] CNN Indonesia.(2020 Maret 12). WHO Umumkan Virus Corona Sebagai PAndemi. CNN Indonesia.

[3] Koesmawardhani, N. W. (2020, Maret 17). Pemerintah Tetapkan Masa Darurat Bencana Corona hingga 29 Mei 2020. Detiknews.

[4] CNN Indonesia. (2020, Maret 14). Mengenal Social Distancing sebagai Cara Mencegah Corona. CNN Indonesia.

[5] Gugus Tugas Percepatan Penanganan Covid 19. Sebaran kasus COVID 19 di Indonesia. Covid19.

[6] Pemerintah Provinsi Jawa Tengah. Sebaran Kasus Covid-19 di Jawa Tengah. Corona Jateng Prov.

[7] Ayun, P. (2015). Fenomena Remaja Menggunakan Media Sosial dalam Membentuk Identitas. Jurnal Channel, Vol 3, 1-16.

[8] Siddiqui, S., \& Singh, T. (2016). Social media its impact with positive and negative aspects. International Journal of Computer Applications Technology and Research,5(2), 71-75.

[9] Elefant, C. (2011). The "power" of social media: Legal issues and best practices for utilities engaging social media. Energy Law Journal,32(1), 1-56.

[10] McFarland, L. A. \& Ployhart, R. E.. (2015). Social media: A contextual framework to guide research and practice. Journal of Applied Psychology, 100(6), 1653-1677.

[11] Robbins, \& Stephen, P. J. (2008). Essentials of The Organizational Bahavior. In D. Angelica, Perilaku Organisasi Buku 1 Edisi 12. Jakarta: Salemba Empat

[12] Turban, E., King, D., Lee, J. K., Liang, TP., \& Turban, D. C. (2015). Electronic Commerce: A Managerial and Social Networks Perspective (8th ed). Switzerland: Springer International Publishing.

[13] Machado, L., Tavares, H, et all. (2015). Happines and Health in Psychiatry: What are Their Implications. Journal Clinical Psychiatry vol.42 no.4

[14] Center for Substance Abuse Treatment (US). Trauma-Informed Care in Behavioral Health Services. Rockville (MD): Substance Abuse and Mental Health Services Administration (US); 2014. (Treatment Improvement Protocol (TIP) Series, No. 57.) Chapter 3, Understanding the Impact of Trauma.

[15] Han Y, Yang H. The transmission and diagnosis of 2019 novel coronavirus infection disease (COVID-19): A Chinese perspective. J Med Virol. 2020;

[16] Bai Y, Yao L, Wei T, Tian F, Jin D-Y, Chen L, et al. Presumed Asymptomatic Carrier Transmission of COVID-19. JAMA. 2020; published online February 21. DOI: 10.1001/jama.2020.2565

[17] Prevention CfDCa. Interim US Guidance for Risk Assessment and Public Health Management of Persons with Potential Coronavirus Disease 2019 (COVID-19) Exposures: Geographic Risk and Contacts of Laboratory-confirmed Cases [Internet]. 2020

[18] World Health Organization. Global surveillance for COVID-19 disease caused by human infection with the 2019 novel coronavirus. Geneva: World Health Organization; 2020

[19] Kampf, Gunter.2017. Efficacy of Ethanol Against Viruses in hand disinfection. Journal of Hospital Infection

[20] Jane Lee Jia Jing, Thong Pei Yi, et.all. 2020. Hand Sanitizer: A Review on Formulation Aspects, Adverse Effect, and Regulations. International Journal of Environmental Research and Public Health 17(9): 3326 Published online 2020 May 11.

[21] Van Doremalen N, Bushmaker T, Morris DH, Holbrook MG, Gamble A, Williamson BN, et al. Aerosol and Surface Stability of SARS-CoV-2 as Compared with SARS-CoV-1. N Engl J Med. 2020; 